\title{
Supply Chain Flexibility and Financial Performance in the Emergent Market "Morocco case study".
}

\author{
Lemtaoui Morad ${ }^{a}$, Rochdi Mohamed Houssam ${ }^{b}$, Hajar Rajic, * \\ ${ }^{a}$ ENCG-Settat, Hassan 1 University, Settat, Morocco, LEMTAOUIMORAD@yahoo.fr \\ ${ }^{b}$ ENCG-Settat, Hassan 1 University, Settat, Morocco, M.H.ROCHDI@gmail.com \\ 'ENCG-Settat, Hassan 1 University, Settat, Morocco, HAJAR.RAJI@live.fr \\ *Corresponding author.
}

Received: 30 July 2018, accepted: 24 Septembre 2018, published: 31 January 2019

\begin{abstract}
Today, and especially in the emergent market, the company success is directly linked to its capacity to deal with the highly changing environment, and how much its supply chain is flexible regarding these changes. The paper analyses how the supply chain flexibility impacts the firms' financial performance in the emergent market, taking Morocco as a study case due to what this country demonstrated as economical resilience during the recent economic crisis and during the "Arab Spring", by applying a multiple linear regression model. The result suggests that the supply chain flexibility has a significant impact on the firms' revenue growth, confirming that today the supply chain flexibility is a key element in the company's business sustainability.
\end{abstract}

Keywords: Supply chain, revenue growth, Moroccan industry, Supply chain flexibility

JEL codes: G39, M11, 04,

\section{INTRODUCTION}

The emergent market is a market where growth is fast and where demand is strong. In financial terms, an emerging market is a dynamic market that attracts investments from all over the world, but remains a high risky market, where the slightest jolt or the slightest reversal of trends may result in a massive withdrawal of capital. Indeed, emerging markets are often narrow markets, and any change can be very abrupt, on both ways.which impacts directly the companies as main stakeholders, making mandatory for them to develop a certain supply chain flexibility to face these continuous environment changes.

\section{LITERATURE REVIEW}

The logistics chain management requires the mastery of a set of managerial practices ranging including the supply of raw materials, the manufacturing and assembly of products, the management of warehouses and stocks, the business intelligence related the management of the logistics chain, supply and demand, and up to the distribution and delivery of finished products (Agus, 2010), each of the managerial practices mentioned above requires a certain flexibility to be able to consequently lead to a supply chain fully adapted to the managerial decisions, decisions that are often dictated by the high changing external environment, however this flexibility was until 1990 associated only with industrial or manufacturing flexibility, and it is only from the earlier nineteenth that the awareness that flexibility is at a certain degree a measure of the potential behaviour of the firm's external environment change started, (Upton, 1995), which is also reflected in how the extent of the supply chain's flexibility changed in the last three decades, where several http://dx.doi.org/ 10.30585/icabml-cp.v2i1.168

(C) 2018 the Authors. Production and hosting by Avicenna FZ LLC. on behalf of Dubai Business School, University of Dubai - United Arab Emirates. This is an open access article under the CC BY-NC license. 
typologies have been described, (Slack, 1983) has described five types of flexibility (new product, product combination, quality, volume and delivery), (Gerwin, An agenda for research on the flexibility of manufacturing processes, 1987) has described seven types of flexibility, while (Vokurka, 2000) presented 15 different flexibility dimensions (machine, material handling, operations, automation, work, process, routing, product, new design, delivery, volume, expansion, program, production and market).

\subsection{Supply chain flexibility definition}

For a long time, supply chain flexibility has been a subject of debates, for a while it was associated only with the procurement flexibility, if for (Weele, 2010) procurement is a function of purchasing materials including raw materials, consumable goods and services, (Waters, 2009) came with a more simplistic definition that considers procurement as a function responsible for procuring all the material needed by an organization and that the purchasing function consists of the activities and services aiming to handle all suppliers needs and requirements, nevertheless the notion of procurement was always confused with the procurement function, so the study of the purchasing function is important to understand the scope of the procurement function, (MOIGNE, 2013) said "Charles Babbage is, it seems, the first author to approach the purchasing function in his book On the Economy of Machinery and Manufactures in 1832", (Vokurka, 2000) highlighted several dimensions of supply chain flexibility, most of which have already been presented by (Koste, 1999), which focused on manufacturing flexibilities. Even though the latter has added other aspects of flexibility, mainly the flexibility of delivery and the flexibility of the markets, confirming that this manufacturing flexibility requires upstream supply flexibility, which has been subdivided into several dimensions and which requires an interorganizational sharing of data.

Some researchers, as is the case of (Gerwin, Manufacturing flexibility: a strategic perspective, 1993) believes that a flexible system of operations requires the management and control of different dimensions of flexibility, by analysing the total flexibility of the supply chain system. Which is based according to (Lee, 2004) on three distinctive components. These components are the basic criteria of any flexible supply chain,

- Adaptability: Supply chain should have an adaptable design so that it can respond to structural changes in markets and align with any changes in strategies.

- Alignment: Create incentives along supply chain partners for better overall performance.

- Agility: The ability of a supply chain to respond quickly to short-term changes in demand or supply and manage external disruptions smoothly.

Although alignment is considered to be one of the aspects of flexibility, this is seen as a prerequisite for a supply chain to deal with uncertainty so a supply chain can only react effectively to the changes when a common agreement is reached between all supply chain partners and a change of strategy is needed.

In conclusion of the above, we define the supply chain flexibility as the ability to respond to short-term changes in demand or supply situations from other external disturbances as well as adjustment to strategic and structural changes in the supply chain environment.

\subsection{Supply flexibility dimensions}

Flexibility combines agility and adaptability (Lee, 2004), this adaptability is characterized in the different aspects of the supply chain flexibility and at different levels, at the level of the buyer-supplier relationship, at the level of demand and the role of marketing, as well as at the level of the production / manufacturing aspect, (Kopecka, 2015), which pushes us to define several dimensions of the supply chain:

- Product Flexibility: It is the ability of the company to adapt product design to any future changes, including new products and any new variances of the existing products, which allows a faster response to customization requests and simplifies the processing of non-standard orders. The postponement as an example of late product variation allows companies to trigger the start of product differentiation only when a clear demand signal is available to keep the product until then in a form standardized (Stevenson\&Spring, 2007)

- Flexibility of quantities: it is the ability of the company to vary production levels below or above planned levels, in response to fluctuations in demand. 
- the flexibility of the purchases: it is the ability to have several suppliers able to supply to the same specific need, with more or less similar quality-price ratios, in the case where the suppliers are not able to provide the required quantities of a product or if it does not meet the required quality, the company must be flexible enough to have substitute suppliers that can meet the supplying expectations (Kumar V., 2006), and in order that a supplier can be considered "flexible" it should offer different delivery models regarding the timing, quantity and location of the desired product or service, while complying with customer requirements (Singh, 2013).

- Flexibility of access: is linked to the possibility of having several distribution and sales channels focusing on the needs of direct and indirect customers, providing a wide coverage for both retailers and wholesalers, facilitated by supply chain's close coordination of downstream activities.

- Flexibility of the workforce: is the ability to split tasks over a large number of operators. It refers to the flexibility of employees to work in different production's positions, but also to work in different models of change of position. Work flexibility allows multitasking and the execution of various tasks.

- Flexibility of delivery: It is the ability of an organization to adapt the delivery frequency According to the customer needs, and the ability to synchronize times and quantities accordingly, it also refers to the ability to change the mode of transport if necessary.

On the below table we summarized a literature review of the different Supply chain flexibility dimensions:

Table 1. Literature review of the Supply chain flexibility dimensions

\begin{tabular}{|c|c|c|c|}
\hline & Year & $\begin{array}{l}\text { Number of } \\
\text { dimensions }\end{array}$ & Dimensions of flexibility \\
\hline (Vickery, 1999) & 1999 & 5 & $\begin{array}{l}\text { Product flexibility, Volume flexibility, Launch flexibility, } \\
\text { Access flexibility, Responsiveness to market(s) }\end{array}$ \\
\hline (Zhang, 2002) & 2002 & 4 & $\begin{array}{l}\text { Product development flexibility, Manufacturing } \\
\text { flexibility, Logistics flexibility, Spanning flexibility }\end{array}$ \\
\hline (Duclos, 2003) & 2003 & 6 & $\begin{array}{l}\text { Operations system flexibility, Market flexibility, Logistics } \\
\text { flexibility, Supply flexibility, Organizational flexibility, } \\
\text { Information systems flexibility. }\end{array}$ \\
\hline (Lummus, 2003) & 2003 & 5 & $\begin{array}{l}\text { Operational systems flexibility, Logistics processes } \\
\text { flexibility, Supply network flexibility, Organizational } \\
\text { design flexibility, Information systems flexibility }\end{array}$ \\
\hline (Garavelli, 2003) & 2003 & 2 & Process flexibility, Logistics flexibility \\
\hline (Pujawan, 2004) & 2004 & 4 & $\begin{array}{c}\text { Sourcing flexibility, New product flexibility, } \\
\text { Manufacturing/production flexibility, Delivering } \\
\text { flexibility }\end{array}$ \\
\hline (Sanchez, 2005) & 2005 & 9 & $\begin{array}{l}\text { Product flexibility, volume flexibility, transshipment flexibility, } \\
\text { Launch Flexibility, sourcing flexibility, logistics flexibility, } \\
\text { delivery flexibility, access flexibility, process flexibility }\end{array}$ \\
\hline (Kumar V., 2006) & 2006 & 4 & $\begin{array}{c}\text { Product flexibility, Launch Flexibility, sourcing flexibility, } \\
\text { delivery flexibility }\end{array}$ \\
\hline $\begin{array}{l}\text { (Stevenson\&Spring, } \\
\text { 2007) }\end{array}$ & 2007 & 6 & $\begin{array}{l}\text { Product flexibility, volume flexibility, logistics flexibility, } \\
\text { Information system flexibility, delivery flexibility, process } \\
\text { flexibility }\end{array}$ \\
\hline (Yu K., 2012) & 2012 & 3 & $\begin{array}{c}\text { Physical Distribution Flexibility, Demand Management } \\
\text { Flexibility, Coordination Flexibility, }\end{array}$ \\
\hline
\end{tabular}

By reviewing the above table we can see clearly that beside the classic physical supply chain flexibility, the supply chain information system flexibility was widely discussed especially with on the increasing role it playing today, as it become the determinant of the success/effectiveness of the supply chain.

Based on that in our analysis we will make the focus on both the supply chain physical flexibility and also on the supply chain information system flexibility. 


\section{Empirical study:}

\subsection{Sample}

\subsubsection{Sample size}

In order to define the sample size that will provide a high confidence level and a low margin of error we used the Cochran's Formula:

Figure 1. Cochran's Formula

$$
\text { Sample size }=\frac{\frac{z^{2} \times p(1-p)}{e^{2}}}{1+\left(\frac{z^{2} \times p(1-p)}{e^{2} N}\right)}
$$

$\mathrm{N}=$ population size $\cdot \mathrm{e}=$ Margin of error (percentage in decimal form) $\cdot \mathrm{z}=\mathrm{z}$-score

And based on the total number of the industrial companies in Morocco 65.505 companies (OMPIC, 2018), and order to guarantee a $95 \%$ of confidence level which means that the sample should at $95 \%$ accurately reflects the attitude of the Moroccan industrial sector, and assuming an $8 \%$ margin of error we end up with a targeted sample of 150, compared to an actual sample of 145 responders or $97 \%$ efficiency to the plan.

\subsubsection{Sample characteristics}

In order to guarantee an optimal representativeness was considered as the major issue, and since the reactivity and efficiency of the supply chain is more tangible at all it aspects in the industrial sector, the focus on the sample was on the industrial firms, and in order to guarantee a high representativeness, we used the historical data to forecast the percentage of the sample size for each industrial sector component based on their contributions in the total GDP of the country, and in order to do so we aligned our sample to the current growth industry sector on a total level and on subcomponent level, where we took for the 2000-2007 and the 2008-2013 sectorial analysis (Haut Commissariat au Plan, 2014), and based on the observed growth trends we forecasted the 2015-2020 projections, where we estimated the share of it each single industrial component contribution in the total sample.

Table 2 Sample size and weight

\begin{tabular}{|c|c|c|c|c|c|c|c|c|}
\hline & \multirow{2}{*}{\multicolumn{2}{|c|}{ 2000-2007 period }} & \multirow{2}{*}{\multicolumn{2}{|c|}{ 2008-2013 period }} & & & & \\
\hline & & & & & \multicolumn{2}{|c|}{ 2015-2020 projections } & \multicolumn{2}{|c|}{ sample } \\
\hline & GDP \% & $\begin{array}{c}\text { industrial sector } \\
\text { share }\end{array}$ & GDP \% & $\begin{array}{c}\text { industrial sector } \\
\text { share }\end{array}$ & $\begin{array}{c}\text { growth } \\
\%\end{array}$ & $\begin{array}{c}\text { industrial sector } \\
\text { share }\end{array}$ & $\begin{array}{l}\text { sample } \\
\text { size }\end{array}$ & $\%$ \\
\hline Food and tobacco industries & $3.7 \%$ & $28.5 \%$ & $4.0 \%$ & $34.8 \%$ & $22.1 \%$ & $30.0 \%$ & 44 & $30.0 \%$ \\
\hline Textile and leather industries & $3.3 \%$ & $25.4 \%$ & $2.2 \%$ & $19.1 \%$ & $-24.7 \%$ & $10.5 \%$ & 15 & $10.5 \%$ \\
\hline Chemical and parachemical industries & $3.3 \%$ & $25.4 \%$ & $2.9 \%$ & $24.8 \%$ & $-2.5 \%$ & $17.6 \%$ & 26 & $17.6 \%$ \\
\hline Mechanical, metallurgical ndustries & $2.7 \%$ & $20.8 \%$ & $2.5 \%$ & $21.4 \%$ & $2.9 \%$ & $16.0 \%$ & 23 & $16.0 \%$ \\
\hline Other manufacturing industries & $1.6 \%$ & $12.3 \%$ & $2.4 \%$ & $20.9 \%$ & $69.4 \%$ & $25.8 \%$ & 37 & $25.8 \%$ \\
\hline Total & $13.0 \%$ & $100.0 \%$ & $11.5 \%$ & $100.0 \%$ & $13.5 \%$ & $100.0 \%$ & 145 & $100.0 \%$ \\
\hline
\end{tabular}

\subsection{Data gathering methodology}




\subsubsection{Financial data}

We chose the use the revenue growth as main indicator to assess the relationship between the financial performance of the company and it supply chain flexibility because the revenue growth is not only a contextual metric that provides a comparative progress ( year over year ), and absolute figures ( current results) but more than that, it reflects clearly how the overall Business development and marketing strategies are successful, and how much they are aligned with the customer needs and the internal processes capabilities, and specially the synergy that exists between the decisions making and the supply chain abilities and on the top of it the supply chain flexibility.

Having access to reliable financial information was a major concern, as long as the Moroccan law ${ }^{1}$ is obliging only the listed companies to publish their financials, and as only 74 Moroccan companies are listed on the Casablanca Stock Exchange (Bourse de Casablanca, 2017), it was not possible to rely only on the stock exchange market published financial.

To resolve this issue, we have approached the Moroccan Office of Industrial and Commercial Property (OMPIC), and also by using the "Directinfo" " platform we had access the basic accounting information for each targeted company that we used in order to booked revenue numbers, and starting from the most recent financial data, we analysed the information for three consecutive years, and as per what is shown on the below graph, we can see that more than $90 \%$ of the financial information refers to the most recent data from the period 2015-2017.

Figure 2. Financial data reference period

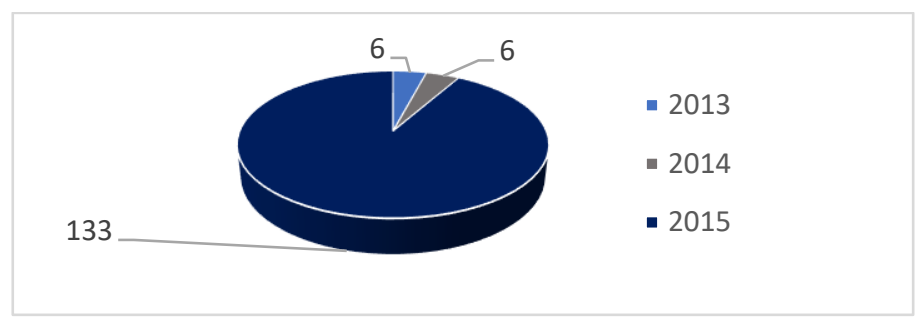

\subsubsection{Questionnaire}

The questionnaire administration was either by I-forms or the responses were manually key entered based on the responders feedback, and multiple versions of the questionnaire were tested through reviews done by directors, supervisors and team leaders of various functions to check visibility, understanding and accuracy of the questions, on based on their feedbacks several minor changes were made, (DILLMAN, 2009), the responders were contacted via several channels including Linkedln, emails, phone calls....

And in order to guarantee a high responding rate we chose the take lead approach, where personalized messages were prepared based on the responders' background and function, and a continuous follow up, with three trials for each responder if no response is received.

And the response rate was $26 \%$ as 145 response was received out of the 557 contacted persons,

\subsection{Analysis}

In order to provide a clear response to the question of how the supply chain flexibility is impacting the companies' financial performance?, we used the multiple linear regression model in order to perform our multidimensional analysis, we started by defining the variables including the control variables and the supply chain flexibility variables, in order to assess how the supply chain flexibility is influencing the companies' revenue growth.

\subsubsection{Research Model}

\footnotetext{
${ }^{1}$ Act 12-4 law $n^{\circ}$ 1-93-212 / 21 September 1993 related to the required information from listed companies

${ }^{2} \mathrm{E}$-commerce website of the OMPIC online services
} 


\subsubsection{Control variables}

In order to make sure that our regression analysis is not corrupted by the companies size and industry types, we introduces them as control variables, where they were entered as a first hierarchy in the multiple regression model in order to verify their impact on the revenue growth of the company before testing the supply chain flexibility variables.

- Company Size (TE): as defined by the OECD "A company is a legal entity entitled to carry out activities for its own account, for example to sign contracts, own property, incur debts and open bank accounts. It can be a corporation, a quasi-corporation, a non-profit entity or an unincorporated business. Companies can be classified according to their size; different criteria can be used for this purpose, but the most common is the number of employees. Small and medium-sized enterprises (SMEs) employ fewer than 250 employees and are subdivided into micro-enterprises (fewer than 10 employees), small enterprises (10 to 49 employees), and medium-sized enterprises (50 to 249 employees). Large companies employ at least 250 employees. This indicator is expressed in the number of employees in the manufacturing sector. (OECD, 2018), according to that definition only one criteria was used to assess the size of the company which is the number of employees.

- Industry type (TI): this control variable was introduced in order to eliminate the impact of the logistics processes that are specific to each type of industries which may have a significant impact on the revenue growth, and also to verify if there is any correlation between the industry type and the revenue growth, that may compromise our regression model accuracy.

\subsubsection{Supply chain flexibility variables}

As per what was discussed on the literature review, and in order to assess the supply chain flexibility we chose to use two main variables the first one is related to the physical supply chain flexibility and the second one is related to the information system flexibility:

- Physical supply chain flexibility:, we used the literature review in order to set several dimensions that need to be a part in it conception of the physical supply chain flexibility variable, meanwhile we requested the responders to consider this sub variable either when it comes to the inputs (purchases) or outputs (provided goods or services) of their companies.

Six sub variables were considered to assess the physical supply chain flexibility variable, and for which we asked the responders to rate actual status using a Likert scale, then the mean was used the asses the overall variable, these sub variables aimed to measure how the company supply chain is flexible in terms of quantity change (FA1), delivery time change (FA2), and delivery place change (FA3) and how they will rate their supply chain in terms of delivery time (FS2), customer satisfaction (FS3), and order compliance (FS1) for which we clearly specified the extent to the responders based on the definition of the French consumer code ${ }^{3}$ where an order is compliant only if:

- It corresponds to the description given by the seller and possesses the qualities that he has presented to the buyer in the form of a sample or a model;

- it has the qualities that a buyer can legitimately expect given the public statements made by the seller, the producer or his representative, including advertising or labelling;

- Or if it has the characteristics defined by mutual agreement by the parties or is suitable for any special use sought by the buyer, made known to the seller and that the latter has accepted.

- Information systems flexibility: for the I.S flexibility we chose to use three main sub variables that contribute in maintaining of flexible information system, and for which we asked also the responders to rate the perception of the actual status using a Likert scale and then the mean was used the asses the overall variable, we started with the information sharing and the data exchange (SI1) sub variable fully discussed under the (ISO-10303, 2012) also known as Automation systems and integration "STEP" can be used as a reference for the best practices. the second sub variable that was used was the integration of databases into the companies

\footnotetext{
${ }^{3}$ Article L. 217-5 of the French Consumer Code
} 
applications (SI2), or what we can define as the software and databases architecture that ensure the system interconnection, which is extremely critical in the supply chain flexibility, as today's intra enterprise systems communication become extremely complex, especially with the increasing number of databases including the endpoints, the cloud, employee interaction, and consumer demand in real time. The third sub variable that was used was the assessment of how much the access to the integrated databases is easy and secured (SI3), as long as the easiness of the access to the integrated databases can result to a huge time saving, thus impacting positively the overall supply chain flexibility, and also provide faster and more accurate reporting to the high management for a better decision making, reducing also the security breaches that can cause huge financial damages to the company.

All the discussed above control and model variables are represented in the below figure:

Figure 3.Research Model

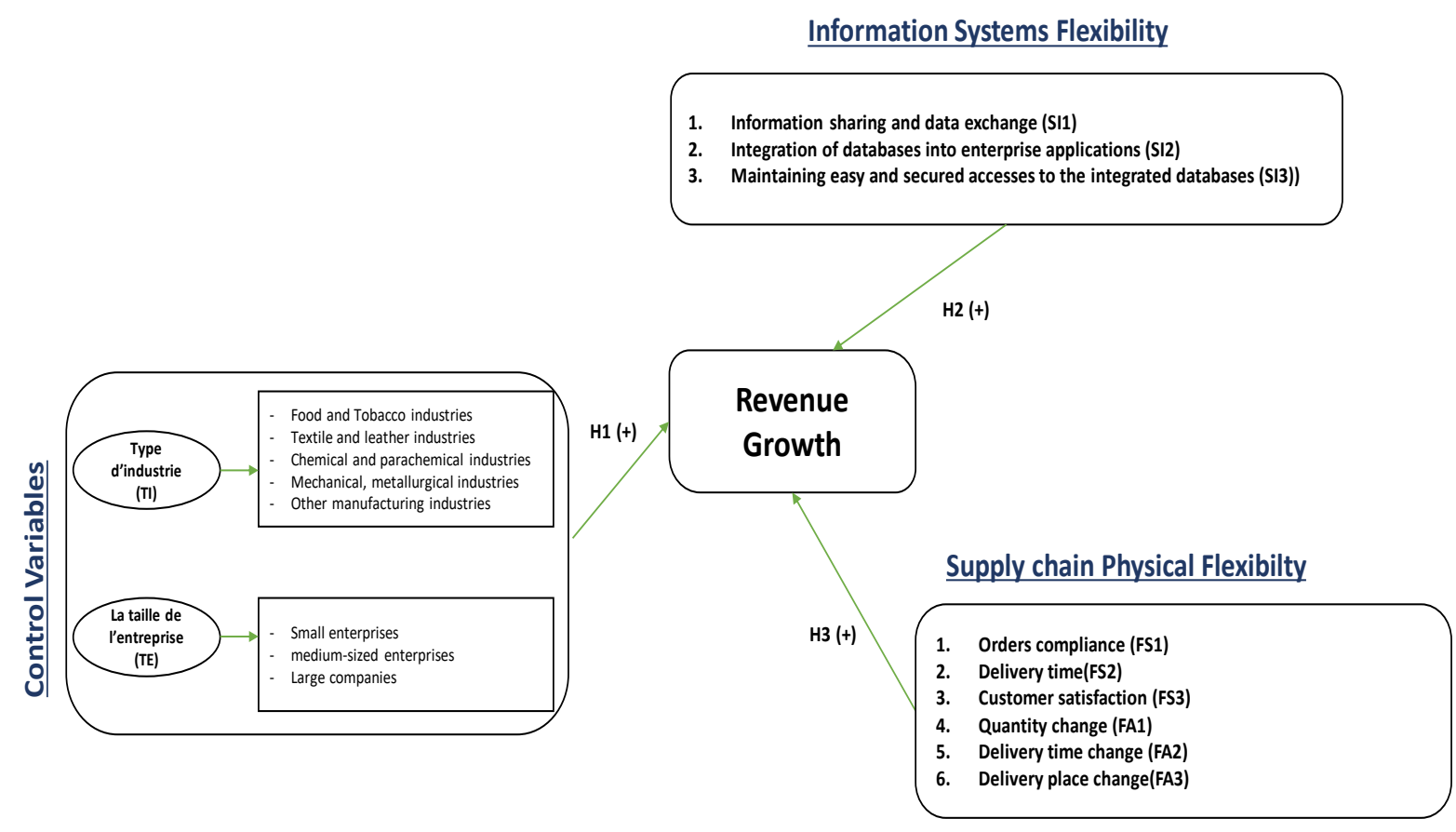

\subsubsection{Regression model}

In order to analyse our model we chose to use multiple linear regression by testing the relationship between the dependent variable revenue growth and the independent variables either the control variables, or the supply chain flexibility variables, through the below regression equation:

$\mathrm{CA}=\alpha+\beta 1^{*} \mathrm{TE}+\beta 2 * \mathrm{TI}+\beta 3 * \mathrm{SI}+\beta 4 * \mathrm{FL}+\mathrm{E}$ Where:

CA = Dependent variable revenue growth

$\mathrm{TE}=$ Independent variable company size

$\mathrm{SI}=$ Independent variable information systems flexibility

$\mathrm{FL}=$ Independent variable supply chain physical flexibility

$\mathrm{E}=$ Residuals 
Then the non-significant variables where removed from the model,

\subsection{Results}

Through the analysis of the correlations, we can see that there is no significant correlation between the control variables and the revenue growth, while we notice that there a significant positive correlations $>0.6$ between both supply chain flexibility variables and the revenue growth, as shown in the Table 3.

Table 3. Correlations' Analysis

\begin{tabular}{|c|c|c|c|c|c|c|}
\hline \multicolumn{7}{|c|}{ Correlations } \\
\hline & & Revenue growth & $\begin{array}{l}\text { Information } \\
\text { Systems } \\
\text { Flexibility } \\
\end{array}$ & $\begin{array}{l}\text { Physical Supply } \\
\text { Chain Flexibility }\end{array}$ & industry & Company size \\
\hline \multirow{6}{*}{ Pearson Correlation } & Revenue growth & 1,000 &, 686 &, 643 & 126 &,- 082 \\
\hline & Information Systems Flexibility &, 686 & 1,000 & 818 & , 175 &,- 007 \\
\hline & Physical Supply Chain & 643 & .818 & 1.000 & 097 & -.030 \\
\hline & Flexibility & & & & & \\
\hline & industry &, 126 & , 175 &, 097 & 1,000 & 049 \\
\hline & Company size &,- 082 &,- 007 &,- 030 &, 049 & 1,000 \\
\hline
\end{tabular}

And in order the isolate the effect of the control variables in our model, we chose the hierarchical multiple linear regression by using the method "Enter " for the first model, and excluding the non-significant variables in the second model through the method "Remove".

Table 4. Variable Entered/Removed

\begin{tabular}{|c|c|c|c|}
\hline \multicolumn{4}{|c|}{ Variables Entered/Removed ${ }^{a}$} \\
\hline Model & Variables Entered & $\begin{array}{l}\text { Variables } \\
\text { Removed }\end{array}$ & Method \\
\hline 1 & $\begin{array}{l}\text { Company size, } \\
\text { Information } \\
\text { Systems } \\
\text { Flexibility, } \\
\text { industry, Physical } \\
\text { Supply Chain } \\
\text { Flexibility } \\
\end{array}$ & $\begin{array}{c}\text { industry, } \\
\text { Company size }^{c}\end{array}$ & 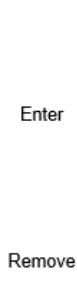 \\
\hline
\end{tabular}

As shown on the below model summary table, we can see that the coefficient of the multiple linear regression for the first model is $R=0,704$ and in the second model where the control variables were removed it is $R=0.700$, which demonstrates that the industry type and the enterprise size don't have a significant impact in the prediction of the revenue growth, and that the compilation of the both supply chain flexibility variables, information systems flexibility and supply chain physical have a significant impact on the prediction of the revenue growth,

The $\mathrm{R}^{2}=0.490$ shows that the supply chain flexibility variables contribute significantly to explain the revenue growth of the company, and we consider 0.490 as a high ratio especially revenue growth is multidimensional variable and it depends on several variables other than supply chain ones, as for instance pricing, marketing, long term strategy ....

The Durbin-Watson test result which is close to 2 , demonstrates that there is no autocorrelation in the sample 
Table 5. Model Summary

\begin{tabular}{|c|c|c|c|c|c|c|c|c|c|c|}
\hline \multicolumn{11}{|c|}{ Model Summary ${ }^{c}$} \\
\hline \multirow[t]{2}{*}{ Model } & \multirow[t]{2}{*}{$\mathrm{R}$} & \multirow[t]{2}{*}{ R Square } & \multirow{2}{*}{$\begin{array}{l}\text { Adjusted R } \\
\text { Square }\end{array}$} & \multirow{2}{*}{$\begin{array}{l}\text { Std. Error of the } \\
\text { Estimate }\end{array}$} & \multicolumn{5}{|c|}{ Change Statistics } & \multirow[t]{2}{*}{ Durbin-Watson } \\
\hline & & & & & $\begin{array}{l}\text { R Square } \\
\text { Change }\end{array}$ & F Change & df1 & $\mathrm{df} 2$ & Sig. F Change & \\
\hline 1 &, $704^{3}$ & ,496 & ,481 & , 14824 & 496 & 34,429 & 4 & 140 &, 000 & \\
\hline 2 &, $700^{b}$ & .490 & .483 & , 14800 &,- 006 &, 766 & 2 & 140 & ,467 & 2,039 \\
\hline
\end{tabular}

a. Predictors: (Constant), Company size, Information Systems Flexibility, industry, Physical Supply Chain Flexibility

b. Predictors: (Constant), Information Systems Flexibility, Physical Supply Chain Flexibility

c. Dependent Variable: Revenue growth

The F-ratio for the second model shows that overall regression model is a good fit for the data, as long as independent variables significantly predict the revenue growth, $\mathrm{F}(2,142)=68.317$ where $p<.0005$, so we can reject the Null hypothesis, and confirm that the supply chain flexibility variables have a significant impact on the revenue growth.

Table 6.ANOVA Results

\begin{tabular}{|c|c|c|c|c|c|c|}
\hline \multicolumn{7}{|c|}{ ANOVA $^{\mathrm{a}}$} \\
\hline Mor & & Sum of Squares & df & Mean Square & $\mathrm{F}$ & Sig. \\
\hline \multirow{4}{*}{1} & Regression & 3,026 & 4 & ,757 & 34,429 &, $000^{\mathrm{b}}$ \\
\hline & Residual & 3,077 & 140 & ,022 & & \\
\hline & Total & 6,103 & 144 & & & \\
\hline & Regression & 2,993 & 2 & 1,496 & 68,317 &, $000^{\circ}$ \\
\hline \multirow[t]{2}{*}{2} & Residual & 3,110 & 142 & 022 & & \\
\hline & Total & 6,103 & 144 & & & \\
\hline
\end{tabular}

a. Dependent Variable: Revenue growth

b. Predictors: (Constant), Company size, Information Systems Flexibility, industry, Physical Supply Chain Flexibility

c. Predictors: (Constant), Information Systems Flexibility, Physical Supply Chain Flexibility

The previous analysis showed that control variables have no significant impact on the revenue growth so in our regression model we excluded them and used only the second model through the below regression equation :

$C A=\alpha+\beta 1 * S I+\beta 2 * F L+E$

As shown on the below coefficients analysis, the constant or the constant or the $Y$ intercepts is -0.297 from which we can deduct our regression equation:

$\mathrm{CA}($ Predicted $)=-0.297+0,058 * \mathrm{SI}+0,032 * \mathrm{FL}+\mathrm{E}$

The t-statistics and their associated 2-tailed p-values are confirming that the control variables don't have a significant impact on the revenue growth revenue $p=0.719$ and $p=0,232$, while the supply chain flexibility variables have a significant impact on revenue growth, the $p<0.0005$ for the information systems flexibility variable and $p=0,019$ making both of them below 0,05 .

Variance inflation factor for all variables is below 5 , so we can say that there is no significant multicolinearity between the independent variables 
Table 7. Coefficients Analysis

\begin{tabular}{|c|c|c|c|c|c|c|c|c|c|c|}
\hline \multicolumn{11}{|c|}{ Coefficients $^{\mathrm{a}}$} \\
\hline \multirow[t]{2}{*}{ Model } & & \multicolumn{2}{|c|}{ Unstandardized Coefficients } & \multirow{2}{*}{$\begin{array}{c}\begin{array}{c}\text { Standardized } \\
\text { Coefficients }\end{array} \\
\text { Beta } \\
\end{array}$} & \multirow[t]{2}{*}{$\mathrm{t}$} & \multirow[t]{2}{*}{ Sig. } & \multicolumn{3}{|c|}{ Correlations } & \multirow{2}{*}{$\begin{array}{c}\text { Collinearity } \\
\text { Statistics } \\
\text { VIF } \\
\end{array}$} \\
\hline & & B & Std. Error & & & & Zero-order & Partial & Part & \\
\hline \multirow{8}{*}{2} & (Constant) & -248 &, 059 & & $-4,196$ &, 000 & & & & \\
\hline & $\begin{array}{l}\text { Information Systems } \\
\text { Flexibility }\end{array}$ & ,058 & ,013 &, 481 & 4,546 &, 000 & ,686 & ,359 & ,273 & 3,107 \\
\hline & $\begin{array}{l}\text { Physical Supply Chain } \\
\text { Flexibility }\end{array}$ & ,031 & ,013 &, 245 & 2,341 &, 021 & ,643 & ,194 & , 140 & 3,044 \\
\hline & industry & ,003 & , 009 & ,022 &, 360 & ,719 & , 126 & 030 & ,022 & 1,041 \\
\hline & Company size &,- 023 & , 020 &,- 072 & $-1,200$ & ,232 &,- 082 & -101 &,- 072 & 1,004 \\
\hline & (Constant) & -297 &, 032 & & $-9,420$ &, 000 & & & & \\
\hline & $\begin{array}{l}\text { Information Systems } \\
\text { Flexibility }\end{array}$ &, 058 &, 013 &, 483 & 4,643 &, 000 &, 686 &, 363 &, 278 & 3,020 \\
\hline & $\begin{array}{l}\text { Physical Supply Chain } \\
\text { Flexibility }\end{array}$ & ,032 & , 013 & ,247 & 2,376 & 019 & ,643 & 196 & 142 & 3,020 \\
\hline
\end{tabular}

a. Dependent Variable: Revenue growth

All the applied above tests demonstrated that the supply chain flexibility influence directly the companies' revenue growth, while the control variables have no significant impact on the dependant variable.

\section{CONCLUSIONS}

The study examined how the supply chain flexibility impacts the firms' revenue growth in the emergent market taking morocco as case study, a panel data of 145 companies was analysed using the multiple linear regression model,

The result suggests that the supply chain flexibility which is characterized by its physical flexibility and its information systems flexibility is a key factor influencing the firms' revenue growth. Therefore the supply chain flexibility variables contribute significantly to explain the revenue growth of the company, but it needs to be aligned with the whole strategy of the company, in order to optimize its impact.

\section{References}

Agus, A. (2010). Supply Chain Management, Process Performance and Business Performance. Conference of the International Journal of Arts and Sciences, (pp. 22-25). Rome-Italie.

Bourse de Casablanca. (2017, Décembre 24). Retrieved Décembre 24, 2017, from http://www.casablancabourse.com/bourseweb/Liste-Societe.aspx?IdLink=20\&Cat=7

DILLMAN, D. A. (2009). Response Rate and Measurement Differences in Mixed-Mode Surveys Using Mail, Telephone,. Social Science Research 38, 1-18.

Duclos, L. K. (2003). A conceptual model of supply chain. Industrial Management \& Data Systems, 103(6), 446-456.

Garavelli, A. C. (2003). Flexibility configurations for the supply chain management. International Journal of Production Economics, 85(2), 141-153.

Gerwin, D. (1987). An agenda for research on the flexibility of manufacturing processes. International Journal of Operations \& Production Management, 7, 38-49.

Gerwin, D. (1993). Manufacturing flexibility: a strategic perspective. Management Science, 39(4), 395-410. 
Haut Commissariat au Plan. (2014). Indice de la production industrielle (Base 100 : 2013) . Rabat.

ISO-10303, I. S. (2012). Industrial automation systems and integration - Product data representation and exchange. Geneva, Switzerland.

Kopecka, J. (2015). Flexibility in supply chain management. Delft: Technical University Delft Landbergstraat.

Koste, L. L. (1999). A theoretical framework for analyzing the dimensions of manufacturing. Journal of Operations Management, 75-93.

Kumar V., F. K. (2006). Implementation and Management Framework for Supply Chain Flexibility. Journal of Enterprise Information Management, 19(3), 303-319.

Lee, H. (2004). A triple-A supply chain. Harvard Business Review, 82, 102-112.

Lummus, R. R. (2003). Supply Chain Flexibility : Building a New Model. Global Journal of Flexible Systems Management, 4(4), 1-13.

MOIGNE, R. L. (2013). Supply chain management. Paris: Dunod.

OECD. (2018, Mars 4). https://data.oecd.org/fr/entrepreneur/entreprises-selon-leur-taille.htm. Retrieved from http://www.oecd.org.

Pujawan, N. (2004). Assessing supply chain flexibility: a conceptual framework and a case study. International Journal of Integrated Supply Management, 1(1), 79-97.

Sanchez, A. a. (2005). Supply Chain Flexibility and Firm Performance: A Conceptual Model and Empirical Study in the Automotive Industry. International Journal of Operations \& Production Management, 25(7), 681-700.

Singh, R. K. (2013). Supply Chain Flexibility: A Frame Work of Research Dimensions. global Journal of Flexible Systems Management, 14(3), 157-166.

Slack, N. (1983). Flexibility as a manufacturing objective. International Journal of Operations, 3(3), 4-13.

Stevenson\&Spring. (2007). Flexibility from a Supply Chain Perspective: Definition and Review. International Journal of Operations \& Production Management, 27(7), 685-713.

Upton, D. (1995, July/august ). What really makes factories flexible ? Harvard Business Review, 74-84.

Vickery, S. N. (1999). Supply chain flexibility: an empirical study. The Journal of Supply Chain Management, 35(3), 16-24.

Vokurka, R. a.-K. (2000). A review of empirical research on manufacturing. Journal of Operations Management, 18, 485-501.

Waters, D. (2009). Supply Chain Management - An Introduction to Logistics. London.: Palgrave MacMillan.

Weele, V. (2010). Purchasing and supply chain management : analysis, planning and practice (4th ed.). London: Thomson.

Yu K., C. J. (2012). Alternative Forms of Fit in Distribution Flexibility Strategies. International Journal of Operations \& Production Management, 32(10), 1199-1227.

Zhang, Q. V.-S. (2002). Value chain flexibility: a dichotomy of competence and capability. International Journal of Production Research, 40(3), 561-583. 
http://dx.doi.org/10.30585/icabml-cp.v2i1.168

(C) 2018 the Authors. International Conference On Advances In Business Management And Law 2018 